\section{Cureus}

Received 01/08/2017

Review began 02/08/2017

Review ended 02/08/2017

Published 02/17/2017

\section{(c) Copyright 2017}

Mehta et al. This is an open access article distributed under the terms of the Creative Commons Attribution License CC-BY 3.0., which permits unrestricted use, distribution, and reproduction in any medium, provided the original author and source are credited.

\title{
Does Vitamin D Deficiency Lead to Hypertension?
}

\author{
Varshil Mehta $^{1}$, Shivika Agarwal ${ }^{2}$ \\ 1. Department of Internal Medicine, Seven Hills Hospital, Mumbai 2. Internal Medicine, Faridabad, India
}

$\square$ Corresponding author: Varshil Mehta, varshil91@gmail.com

Disclosures can be found in Additional Information at the end of the article

\section{Abstract}

Hypertension (HTN) or high blood pressure is one of the most chronic and deadliest disorders in the world. There are many risk factors responsible for HTN which include age, race, using tobacco, high salt intake, etc. One of the risk factors we would like to highlight is low vitamin D levels. While there is strong evidence that Vitamin D plays an important role in maintaining bone and muscle health, there has been recent debate regarding its role in hypertension. However, there are many studies that have shown an indirect relation between 25hydroxyvitamin D serum level and blood pressure. However, we suggest that more studies, especially randomised trials, should be conducted.

Categories: Internal Medicine, Family/General Practice, Endocrinology/Diabetes/Metabolism Keywords: risk factor, htn, vitamin supplementation, 25-hydroxy vitamin d

\section{Introduction And Background}

Hypertension or increase in blood pressure has been considered as one of the leading factors in causing worldwide disability-adjusted life years [1]. HTN has many etiological factors, which include age, race, family history, obesity, sedentary lifestyle, using tobacco, high salt intake, stress, and consuming alcohol in a larger quantity [2].

One of the recent studies by Kearney, et al. showed that more than one billion adults worldwide (approximately 25\%) are suffering from HTN, and there is a possibility that this number will climb up to $29 \%$ by 2025 [3]. The prevalence rate of HTN among Iranian people aged 30 to 55 years old and those over 55 years old is approximately $23 \%$ and $50 \%$, respectively [4].

Hypertension is considered as the fundamental reason for mortality on the planet, the most well-known reason for going to a doctor, and the least complex treatable and recognisable risk factor for diseases like cerebrovascular accident (CVA), myocardial infarction (MI), congestive heart failure (CHF), peripheral artery disease (PAD), atrial fibrillation (AF), and end-stage renal disease (ESRD) [5-6].

Regardless of solid archives showing the reality that treatment of hypertension will diminish the casualty significantly, hypertension is not treated or not totally treated in the vast majority of patients experiencing this issue in entire nations, including nations profiting from the most advanced therapeutic care frameworks. For this reason, hypertension is considered as one of the fundamental general medical problems [7].

In some observational reviews, it has been recognized that hypertension is more prevalent amid chilly months of a year as well as in zones that are a long way from the equator where sun 


\section{Cureus}

radiation is reduced. For every 10 degrees of deviation from the equator, blood pressure and hypertension will rise $2.5 \mathrm{~mm} \mathrm{Hg}$ and $2.5 \%$, respectively [8-10].

More than $40 \%$ of African-Americans in the US experience hypertension while just $25 \%$ of white Americans have such an issue. African-Americans are prone to more severe and earlier hypertension, which further damages target organs and, subsequently, leads to premature disability and death $[5,11-12]$. By this issue, we know that the decline in ultraviolet (UV) radiation, and henceforth, the decrease in the skin's capacity for Vitamin D synthesis, can have a connection with hypertension.

Krause, et al. utilized ultraviolet-B (UVB) light to treat patients with untreated mild essential hypertension (EH) and a deficiency of Vitamin D. These scientists found that UVB radiation, not UVA radiation, led to an increase in 25-hydroxyvitamin $\mathrm{D}(25(\mathrm{OH}) \mathrm{D})$ levels and brought down blood pressure (BP) in Vitamin D-deficient patients with EH. Since 1998, this finding has brought extensive research enthusiasm up in the relationship between vitamin $\mathrm{D}$ inadequacy and $\mathrm{EH}[13]$.

Mehta suggested that low levels of Vitamin D, along with sugar and fats, should be considered as new risk factors in causing hypertension [14]. This article will bring forward the importance of Vitamin D and its role in maintaining blood pressure levels.

\section{Review}

\section{Association of Vitamin D levels and hypertension}

Ultraviolet-B from the sun prompts the development of pre-vitamin D3 from 7-hydrocholesterol in the skin, which then undergoes thermal isomerisation to form vitamin D3. It later undergoes hydroxylation to form 25-hydroxyvitamin D $(25(\mathrm{OH}) \mathrm{D})$ (by the action of 25-hydroxyvitamin-Dhydroxylase) in the liver and subsequently gets converted to 1,25-dihydroxyvitamin D3 (1,25 $\left.\left(\mathrm{OH}_{2}\right) \mathrm{D} 3\right)$ in the kidneys, blood vessels, and heart as shown in Figure 1 [15].
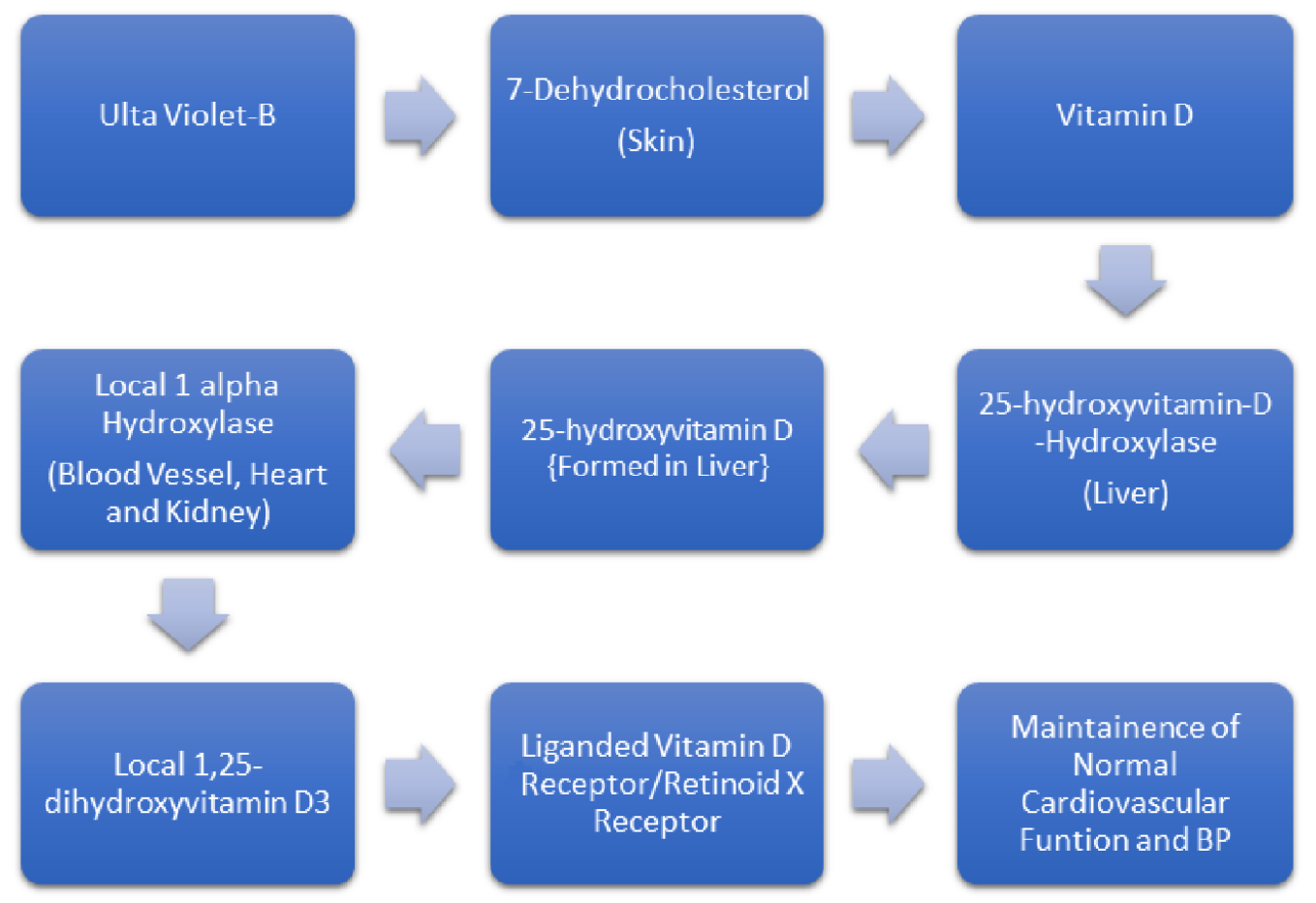

FIGURE 1: Role of Vitamin D in Maintaining Blood Pressure 
Many tissues and organs express VDR, including the heart, endothelium, vascular smooth muscle, and T cells [16-19].

VDR is a nuclear receptor to which Vitamin D3 (VD3) binds with high affinity and specificity. When bound with VD3, VDR is phosphorylated, which leads to a surface conformational change. This VDR is now activated and interacts with the retinoid X receptor (RXR) eventually forming a heterodimer that binds to Vitamin D-responsive elements in the region of gene promoter [20-21].

By recruiting either corepressors or coactivator complexes [22-23], activated VDR/RXR regulates the gene transcription for protein synthesis that modulates the traditional and nontraditional functions of VD3 (e.g., musculoskeletal health, calcium homeostasis, and normal BP and cardiovascular function) [24-25].

Along these lines, we can say that the role of Vitamin D in a cell, tissue, or organ relies on the local production or an adequate measure of VD3, expression levels of VDR/RXR and coreceptor proteins, and cell-specific transcriptional elements to manage genes that encode proteins altering Vitamin D signaling.

\section{Previous clinical studies}

Kota, et al. demonstrated that systolic blood pressure, diastolic blood pressure, and mean arterial pressure had increased among individuals experiencing inadequacy of Vitamin D and proposed that Vitamin D deficiency is associated with renin-angiotensin-aldosterone system (RAAS) regulation [26]. One comparable review demonstrated that individuals with larger amounts of Vitamin D had lower blood pressure and a lower danger of developing hypertension [27].

A study done in 2013 took into account many reviews that included individuals with hypertension. They found that for every $10 \mathrm{ng} / \mathrm{ml}$ increment in Vitamin D levels, a $12 \%$ lower danger of developing hypertension was observed. The general population with the most noteworthy Vitamin D levels had a 30\% lower danger of developing hypertension contrasted with the general population with the least levels. In any case, the greater part of the reviews was done in the United States, implying that we cannot know without a doubt if the outcomes would be the same in different countries [28].

A few studies have taken into account of the impact of Vitamin D on blood pressure in individuals who have hypertension. One such meta-analysis found out that taking Vitamin D supplementation could bring down systolic blood pressure [29].

A study by Jorde, et al. in 2010 exhibited a connection between low serum Vitamin D levels and hypertension. However, no confirmation was discovered showing that a Vitamin D prescription would have the capacity to prevent hypertension in the future [30].

A group of scientists studied the effect of taking a Vitamin D supplement on the risk of hypertension in African-Americans who had normal blood pressure was studied in 2013. These scientists appointed 250 individuals to get either 1,000 IU every day, 2,000 IU every day, 4,000 IU every day, or a placebo for three months. They discovered that for every increase in Vitamin D supplementation and Vitamin D levels in the body, systolic blood pressure declined; however, the diastolic pressure remained the same [31]. 
An experiment in 2012 in Denmark looked at the effects of Vitamin D supplements on lowering blood pressure in people with hypertension. For 20 weeks, people either took 3,000 IU per day of Vitamin D or a placebo pill. The researchers measured a few different types of blood pressure and found that the people in the Vitamin D group lowered their blood pressure more than the people getting the placebo. People in the Vitamin D group who had low levels of Vitamin D at the beginning of the study had a bigger reduction in their blood pressures. Vitamin D may be more effective in lowering blood pressure in people who have low levels of Vitamin D [32].

An Italian study conducted by Carrara, et al. in 2013 reviewed the role of Vitamin D supplementation on regulating the BP in the body. A group of hypertensives was given 25,000 IU per week of Vitamin D for a total of eight weeks. They found out that Vitamin D levels increased throughout the study and BPs were greatly reduced. Hence, they concluded that an overactive blood pressure system can lead to higher blood pressure and Vitamin D may help to reduce the risk of hypertension [33].

To test whether 25(OH)D levels are significantly associated with blood pressure and HTN risk, Vimaleswaran, et al. conducted a study (Mendelian randomization) and used different variants of genes that affect 25(OH)D synthesis or substrate availability (Vitamin D 25-hydroxylase and 7-dehydrocholesterol reductase) to meta-analyse 146,581 participants. They found out that each $10 \%$ increment in genetically instrumented $25(\mathrm{OH}) \mathrm{D}$ concentration was associated with a decrease in systolic $\mathrm{BP}(-0.37 \mathrm{mmHg}, \mathrm{P}=0.052)$ and diastolic $\mathrm{BP}(-0.29 \mathrm{mmHg}, \mathrm{P}=0.01)$, and an $8.1 \%$ reduced odds of HTN $(\mathrm{P}=0.002)$. The findings of a study conducted later, further confirmed that increased 25(OH)D concentrations might decrease the risk of HTN [34-35].

Caro, et al. concluded that serum 25(OH) Vitamin D levels do not have any significant statistical association with blood pressure [36]. In 2008, an experiment used data from a large experiment that assigned women to receive either 1-gram per day of calcium, plus 400 IU per day of Vitamin D, or a placebo pill. They observed that there was no significant difference in blood pressure changes between both the groups [37].

It was shown in a review done by Lee, et al. that serum Vitamin D and parathyroid hormone (PTH) levels have no significant connection in relation to hypertension among Chinese individuals [38]. In a cross-sectional review of 251 individuals (age 40 or more years old) by Kashi, et al., it was discovered that there was no association between hypertension and serum 25(OH) Vitamin D, calcium, and PTH levels [39].

Some other unknown elements might have an impact on the relation between Vitamin D and hypertension, especially in older age groups, as Sanijder reported in his review, which showed Vitamin D effect's on blood pressure might be indirectly based on its role in parathyroid hormone performance [40]. The comparison and findings of all the studies are presented in Table 1.

\begin{tabular}{|c|c|c|c|c|c|c|c|}
\hline Author & $\begin{array}{l}\text { Year of } \\
\text { Publication }\end{array}$ & $\mathbf{N}$ & $\begin{array}{l}\text { Mean } \\
\text { Age } \\
\text { (Years) }\end{array}$ & $\begin{array}{l}\text { Mean } \\
\text { 25(OH)D } \\
\text { (ng/ml) }\end{array}$ & $\begin{array}{l}\text { Mean Systolic Blood } \\
\text { Pressure }(\mathrm{mm} / \mathrm{Hg})\end{array}$ & $\begin{array}{l}\text { Mean Diastolic } \\
\text { Blood Pressure } \\
(\mathrm{mm} / \mathrm{Hg})\end{array}$ & Findings \\
\hline $\begin{array}{l}\text { Kota, et al. } \\
\text { [26] }\end{array}$ & 2011 & 50 & $\begin{array}{l}49.5 \pm \\
7.8\end{array}$ & $\begin{array}{l}18.5 \pm \\
6.4\end{array}$ & $162.4 \pm 20.2$ & $100.2 \pm 11.2$ & $\begin{array}{l}\text { Lower } 25(\mathrm{OH}) \mathrm{D} \text { levels } \\
\text { associated with increased } \\
\text { blood pressure }\end{array}$ \\
\hline $\begin{array}{l}\text { Ullah, et al. } \\
\text { [27] }\end{array}$ & 2010 & - & - & - & - & - & $\begin{array}{l}\text { Larger } 25(\mathrm{OH}) \mathrm{D} \text { levels } \\
\text { associated with lower blood }\end{array}$ \\
\hline
\end{tabular}




\section{Cureus}

Kunutsor, et

al. [28]

Witham, et al.

[29]

\section{Jorde, et al.}

[30]

Forman, et al.

[31]

2007

117,730

Larsen, et al.

[32]

2012

112

Carrara, et al.

[33]

2013

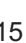

$\begin{array}{ll}43.6 \pm & 18.3 \pm \\ 21.6 & 2.8\end{array}$
Vitamin D

Vimaleswaran,

et al. [34]

Caro, et al.

[36]

Margolis, et

al. [37]

Li, et al. [38]

2012

1,420

Kashi, et al.

[39]
$61 \pm 10 \quad 23 \pm 10$

Decreased by $7 \mathrm{mmHg}$

after taking Vitamin D

supplementation in 24

hrs vs. placebo

At 0 week: $137.4 \pm 1.8$

At 8 weeks (after

supplementation): 134.8

$\pm 2.3$

Decreased by 2

$\mathrm{mmHg}$ after taking

Vitamin D

supplementation vs.

placebo

At 0 week: $81.6 \pm 1.8$

At 8 weeks: $81.0 \pm$

1.6

$73.3 \pm 9.7$

$113.2 \pm 13.1$

$13.5 \pm \quad 29.2 \pm$

$62 \pm 7$ pressure

Larger 25(OH)D levels

associated with lower

chances to develop HTN

Larger 25(OH)D levels

associated with lower

chances to develop HTN

No association between

25(OH)D and HTN

Larger 25(OH)D levels

associated with lower

chances to develop HTN

Vitamin D supplementation

in patients with low levels

of $25(\mathrm{OH}) \mathrm{D}$ brings down

blood pressure

Vitamin D supplementation

in patients with low levels

of $25(\mathrm{OH}) \mathrm{D}$ brings down

blood pressure

Larger 25(OH)D levels

associated with lower blood

pressure

No association between

25(OH)D and HTN

No association between

25(OH)D and HTN

No association between

25(OH)D and HTN

No association between

25(OH)D and HTN

\section{TABLE 1: Comparison and Findings of the Studies}

25(OH)D: 25-hydroxyvitamin D; HTN: hypertension

\section{Conclusions}

Hypertension is one of the most crucial chronic diseases, which can cause many other 
cardiovascular disorders and eventually may lead to death. This article reviews whether serum Vitamin D concentration plays an important role in causing hypertension or not. Because of the opposing consequences of different reviews on the role of Vitamin D in preventing hypertension development or its treatment, it appears that Vitamin D levels in the body modulate the blood pressure indirectly. More studies should be conducted after eliminating the compounding factors in order to prove the association. We suggest that physicians should keep a check on the Vitamin D levels of their patients in order to curb the ever-increasing incidence of hypertension.

\section{Additional Information Disclosures}

Conflicts of interest: In compliance with the ICMJE uniform disclosure form, all authors declare the following: Payment/services info: All authors have declared that no financial support was received from any organization for the submitted work. Financial relationships: All authors have declared that they have no financial relationships at present or within the previous three years with any organizations that might have an interest in the submitted work. Other relationships: All authors have declared that there are no other relationships or activities that could appear to have influenced the submitted work.

\section{References}

1. Murray CJL, Lopez AD: Global mortality, disability, and the contribution of risk factors: Global Burden of Disease Study. Lancet. 1997, 349:1436-42. 10.1016/S0140-6736(96)07495-8

2. Gu JW, Bailey AP, Tan W, Shparago M, Young E: Long-term high-salt diet causes hypertension and decreases renal expression of vascular endothelial growth factor in Sprague-Dawley rats. J Am Soc Hypertens. 2008, 2:275-85. 10.1016/j.jash.2008.03.001

3. Kearney PM, Whelton M, Reynolds K, Muntner P, Whelton PK, He J: Global burden of hypertension: analysis of worldwide data. Lancet. 2005, 365:217-23.

4. Haghdoost AA, Sadeghirad B, Rezazadehkermani M: Epidemiology and heterogeneity of hypertension in Iran: a systematic review. Arch Iran Med. 2008, 11:444-52.

5. Victor RG: Systemic Hypertension: Mechanisms and Diagnosis. Braunwald's Heart Disease: A Textbook of Cardiovascular Medicine, 10th ed. Mann DL, Zipes DP, Libby P, Bonow RO (ed): Saunders, Philadelphia, PA; 2014. 43:934-52.

6. Delavari A, Horri B, Alikhani S, Mahdavi A, Hosseini SM, Haghighi S: Hypertension and prehypertension: Prevalence, awareness and management among Iranian adults older than 20 years (Article in Persian). J Med Council Islamic Rep Iran. 2007, 24:372-80.

7. Chobanian AV: Control of hypertension--an important national priority. N Engl J Med. 2001, 345:534-35. 10.1056/NEJM200108163450709

8. Li YC, Kong J, Wei M, Chen ZF, Liu SQ, Cao LP: 1,25-Dihydroxyvitamin D(3) is a negative endocrine regulator of the renin-angiotensin system. J Clin Invest. 2002, 110:229-38. 10.1172/JCI15219

9. Vaidya A, Williams JS: The relationship between vitamin D and the renin-angiotensin system in the pathophysiology of hypertension, kidney disease, and diabetes. Metabolism. 2012, 61:450-58. 10.1016/j.metabol.2011.09.007

10. Li YC, Qiao G, Uskokovic M, Xiang W, Zheng W, Kong J: Vitamin D: a negative endocrine regulator of the renin-angiotensin system and blood pressure. J Steroid Biochem Mol Biol. 2004, 89-90:387-92. 10.1016/j.jsbmb.2004.03.004

11. Rostand SG: Vitamin D, blood pressure, and African Americans: toward a unifying hypothesis . Clin J Am Soc Nephrol. 2010, 5:1697-703. 10.2215/CJN.02960410

12. Fiscella K, Winters P, Tancredi D, Franks P: Racial disparity in blood pressure: is vitamin D a factor?. J Gen Intern Med. 2011, 26:1105-11. 10.1007/s11606-011-1707-8

13. Krause R, Bühring M, Hopfenmüller W, Holick MF, Sharma AM: Ultraviolet B and blood pressure. Lancet. 1998, 352:709-10. 10.1016/S0140-6736(05)60827-6

14. Mehta V: Emergence of new risk factors for causing hypertension . J Med Res Innov. 2017, 1:911. 
15. Bikle DD: Vitamin D metabolism, mechanism of action, and clinical applications . Chem Biol. 2014, 21:319-29. 10.1016/j.chembiol.2013.12.016

16. Chen S, Glenn DJ, Ni W, Grigsby CL, Olsen K, Nishimoto M, Law CS, Gardner DG: Expression of the vitamin $d$ receptor is increased in the hypertrophic heart. Hypertension. 2008, 52:110612. 10.1161/HYPERTENSIONAHA.108.119602

17. Handel AE, Sandve GK, Disanto G, Berlanga-Taylor AJ, Gallone G, Hanwell H, Drabløs F, Giovannoni G, Ebers GC, Ramagopalan SV: Vitamin D receptor ChIP-seq in primary CD4+ cells: relationship to serum 25-hydroxyvitamin D levels and autoimmune disease. BMC Med. 2013, 11:163. 10.1186/1741-7015-11-163

18. Merke J, Milde P, Lewicka S, Hugel U, Klaus G, Mangelsdorf DJ, et al: Identification and regulation of 1,25-dihydroxyvitamin D3 receptor activity and biosynthesis of 1,25dihydroxyvitamin D3. Studies in cultured bovine aortic endothelial cells and human dermal capillaries. J Clin Invest. 1989, 83:1903-15. 10.1172/JCI114097

19. Mitsuhashi T, Morris RC Jr, Ives HE: 1,25-dihydroxyvitamin D3 modulates growth of vascular smooth muscle cells. J Clin Invest. 1991, 87:1889-95. 10.1172/JCI115213

20. Chen S, Costa CH, Nakamura K, Ribeiro RC, Gardner DG: Vitamin D-dependent suppression of human atrial natriuretic peptide gene promoter activity requires heterodimer assembly. J Biol Chem. 1999, 274:11260-66. 10.1074/jbc.274.16.11260

21. Chen S, Wu J, Hsieh JC, Whitfield GK, Jurutka PW, Haussler MR, Gardner DG: Suppression of ANP gene transcription by liganded vitamin D receptor: involvement of specific receptor domains. Hypertension. 1998, 31:1338-42. 10.1161/01.HYP.31.6.1338

22. Chen S, Cui J, Nakamura K, Ribeiro RC, West BL, Gardner DG: Coactivator-vitamin D receptor interactions mediate inhibition of the atrial natriuretic peptide promoter. J Biol Chem. 2000, 275:15039-48. 10.1074/jbc.275.20.15039

23. Meyer MB, Pike JW: Corepressors (NCoR and SMRT) as well as coactivators are recruited to positively regulated $1 \alpha, 25$-dihydroxyvitamin D3-responsive genes. J Steroid Biochem Mol Biol. 2013, 136:120-24. 10.1016/j.jsbmb.2012.08.006

24. Chen S, Law CS, Grigsby CL, Olsen K, Hong TT, Zhang Y, Yeghiazarians Y, Gardner DG: Cardiomyocyte-specific deletion of the vitamin D receptor gene results in cardiac hypertrophy. Circulation. 2011, 124:1838-47. 10.1161/CIRCULATIONAHA.111.032680

25. Li YC, Kong J, Wei M, Chen ZF, Liu SQ, Cao LP: 1,25-Dihydroxyvitamin D(3) is a negative endocrine regulator of the renin-angiotensin system. J Clin Invest. 2002, 110:229-38. 10.1172/JCI15219

26. Kota SK, Kota SK, Jammula S, Meher LK, Panda S, Tripathy PR, Modi KD: Renin-angiotensin system activity in vitamin D deficient, obese individuals with hypertension: An urban Indian study. Indian J Endocrinol Metab. 2011, 15:S395-401. 10.4103/2230-8210.86985

27. Ullah MI, Uwaifo GI, Nicholas WC, Koch CA: Does vitamin d deficiency cause hypertension? Current evidence from clinical studies and potential mechanisms. Int J Endocrinol. 2010, 2010:579640. 10.1155/2010/579640

28. Kunutsor SK, Apekey TA, Steur M: Vitamin D and risk of future hypertension: meta-analysis of 283,537 participants. Eur J Epidemiol. 2013, 28:205-21. 10.1007/s10654-013-9790-2

29. Witham MD, Nadir MA, Struthers AD: Effect of vitamin D on blood pressure: a systematic review and meta-analysis. J Hypertens. 2009, 27:1948-54. 10.1097/HJH.0b013e32832f075b

30. Jorde R, Figenschau Y, Emaus N, Hutchinson M, Grimnes G: Serum 25-hydroxyvitamin D levels are strongly related to systolic blood pressure but do not predict future hypertension. Hypertension. 2010, 55:792-98. 10.1161/HYPERTENSIONAHA.109.143990

31. Forman JP, Giovannucci E, Holmes MD, Bischoff-Ferrari HA, Tworoger SS, Willett WC, Curhan GC: Plasma 25-hydroxyvitamin D levels and risk of incident hypertension. Hypertension. 2007, 49:1063-69. 10.1161/HYPERTENSIONAHA.107.087288

32. Larsen T, Mose FH, Bech JN, Hansen AB, Pedersen EB: Effect of cholecalciferol supplementation during winter months in patients with hypertension: a randomized, placebocontrolled trial. Am J Hypertens. 2012, 25:1215-22. 10.1038/ajh.2012.111

33. Carrara D, Bernini M, Bacca A, Rugani I, Duranti E, Virdis A, Ghiadoni L, Taddei S, Bernini G: Cholecalciferol administration blunts the systemic renin-angiotensin system in essential hypertensives with hypovitaminosis D. J Renin Angiotensin Aldosterone Syst. 2014, 15:82-87. 10.1177/1470320312471149

34. Vimaleswaran KS, Cavadino A, Berry DJ; LifeLines Cohort Study investigators, Jorde R, Dieffenbach AK, Lu C, Alves AC, Heerspink HJ, Tikkanen E, Eriksson J, Wong A, Mangino M, 
Jablonski KA, Nolte IM, Houston DK, Ahluwalia TS, van der Most PJ, Pasko D, Zgaga L, Thiering E, Vitart V, Fraser RM, Huffman JE, de Boer RA, Schöttker B, Saum KU, McCarthy MI, Dupuis J, Herzig KH, Sebert S, Pouta A, Laitinen J, Kleber ME, Navis G, Lorentzon M, Jameson K, Arden N, Cooper JA, Acharya J, Hardy R, Raitakari O, Ripatti S, Billings LK, Lahti J, Osmond C, Penninx BW, Rejnmark L, Lohman KK, Paternoster L, Stolk RP, Hernandez DG, Byberg L, Hagström E, Melhus H, Ingelsson E, Mellström D, Ljunggren O, Tzoulaki I, McLachlan S, Theodoratou E, Tiesler CM, Jula A, Navarro P, Wright AF, Polasek O; International Consortium for Blood Pressure (ICBP); Cohorts for Heart and Aging Research in Genomic Epidemiology (CHARGE) consortium; Global Blood Pressure Genetics (Global BPGen) consortium; Caroline Hayward, Wilson JF, Rudan I, Salomaa V, Heinrich J, Campbell H, Price JF, Karlsson M, Lind L, Michaëlsson K, Bandinelli S, Frayling TM, Hartman CA, Sørensen TI, Kritchevsky SB, Langdahl BL, Eriksson JG, Florez JC, Spector TD, Lehtimäki T, Kuh D, Humphries SE, Cooper C, Ohlsson C, März W, de Borst MH, Kumari M, Kivimaki M, Wang TJ, Power C, Brenner H, Grimnes G, van der Harst P, Snieder H, Hingorani AD, Pilz S, Whittaker JC, Järvelin MR, Hyppönen E: Association of vitamin D status with arterial blood pressure and hypertension risk: a mendelian randomisation study. Lancet Diabetes Endocrinol. 2014, 2:719-29. 10.1016/S22138587(14)70113-5

35. Afzal S, Nordestgaard BG: Low vitamin D and hypertension: a causal association? . Lancet Diabetes Endocrinol. 2014, 2:682-84. 10.1016/S2213-8587(14)70119-6

36. Caro Y, Negrón V, Palacios C: Association between vitamin D levels and blood pressure in a group of Puerto Ricans. P R Health Sci J. 2012, 31:123-29.

37. Margolis KL, Ray RM, Van Horn L, Manson JE, Allison MA, Black HR, Beresford SA, Connelly SA, Curb JD, Grimm RH Jr, Kotchen TA, Kuller LH, Wassertheil-Smoller S, Thomson CA, Torner JC; Women's Health Initiative Investigators: Effect of calcium and vitamin D supplementation on blood pressure: the Women's Health Initiative Randomized Trial. Hypertension. 2008, 52:847-55. 10.1161/HYPERTENSIONAHA.108.114991

38. Li L, Yin X, Yao C, Zhu X, Wu X: Vitamin D, parathyroid hormone and their associations with hypertension in a Chinese population. PloS one. 2012, $7: \mathrm{e} 43344$.

10.1371/journal.pone.0043344

39. Kashi Z, Mirmiran P, Mehrabi Y, Hedayati M, Azizi F: Association of blood pressure, serum vitamin D, calcium and PTH in individuals over 40 in East Tehran. IJEM. 2004, 5:261-70.

40. Snijder MB, Lips P, Seidell JC, Visser M, Deeg DJ, Dekker JM, van Dam RM: Vitamin D status and parathyroid hormone levels in relation to blood pressure: a population-based study in older men and women. J Intern Med. 2007, 261:558-65. 10.1111/j.1365-2796.2007.01778.x 